\title{
THE FORMATION OF RAISED BEACHES IN SOUTHERN FINLAND DURING THE ANCYLUS AND LITORINA STAGES
}

\author{
TUIJA JANTUNEN and JOAKIM DONNER
}

JANTUNEN, TUIJA and DONNER, JOAKIM, 1996. The formation of raised beaches in southern Finland during the Ancylus and Litorina stages. Bull. Geol. Soc. Finland 68, Part 2, 34-39.

In studies of the shoreline displacement it has generally been accepted that raised beaches were formed during the highest positions of water level during transgressions, before the subsequent regressions, at times when the water level remained long enough (300-1300 years) in the same relative position. There were, however, also similar times for the formation of raised beaches during the relative regressions preceding the transgressions. As a result of this the raised beaches often occur together in pairs, where the older beach of the regression is lower than that of the younger transgression beach. It follows from this new explanation that the former water level fluctuations in the Baltic Sea were fewer than the numerous raised beaches at various altitudes would suggest, as there was only one relative transgression for each pair of raised beaches.

Key words: raised beaches, sea level changes, transgression, regression, uplift, Litorina Sea, Ancylus Lake, Holocene, southern Finland.

Tuija Jantunen, Kämnerinkuja 1 B 25, FIN-00750 Helsinki, Finland. Joakim Donner, Department of Geology, P.O.Box 11, FIN-00014 University of Helsinki, Finland.

\section{INTRODUCTION}

A great number of investigations of the Holocene land/sea level changes in the Baltic Sea area have been undertaken in the 20th century. The interpretations of water level fluctuations and changes in salinity have been based on pollen and diatom studies of profiles of sediments from lakes and mires. In the beginning of the century several raised beaches at different altitudes in southern Finland were referred to as having been formed at the time of the Ancylus Lake as well as during the Litorina Sea stages. In curves showing the relative shoreline displacement the raised beaches were related to small, short-lived transgressions, thus assuming that there were irregularities in the land/sea level changes, especially at the time of the Litorina Sea (7000 
-3000 B.P.). On the other hand, in investigations carried out during the last 20 years it has been concluded that there were at most two Holocene transgressions in the Baltic Sea, one during the Ancylus Lake stage at 9500-9000 B.P. (Glückert, 1991) and another during the Litorina Sea stage at 7000 B.P. (Eronen, 1974). This interpretation does not, however, explain how those raised beaches were formed which occur at several altitudes below the highest Litorina beach in the area of uplift in southern Finland.

The water level changes in the Baltic Sea generally reflected the changes in the oceans, except at times when the Baltic was a separate lake during the Ancylus Lake stage. The formation of raised beaches in the coastal area of Finland was, however, probably also governed by irregularities in the isostatic uplift of this area. Thus, even if the water level did not have great fluctuations the uplift, presumably being jerky after the deglaciation still during the Litorina Sea stage, resulted in the formation of raised beaches at various altitudes.

The aim of the present account is to assess when raised beaches were formed. It was earlier taken for granted that each raised beach was formed during the culmination of a relative transgression of the water level, in land/sea level curves shown as small fluctuations (see Fig. 2). But the question is whether raised beaches could also have formed during the low positions of water level of regressions, before transgressions, as was assumed to have happened in the Porvoo region at about 4800 B.P. (Jantunen, 1995). During a transgression the relative water level stays for some time at about the same level, as it does during a temporary regressive phase, long enough for the formation of a raised beach. Thus, for each raised beach of a transgression there would be another older raised beach, at a lower altitude, of the preceding regression. If this is the case the land/sea level curves for the Baltic Sea would have fewer fluctuations than shown in earlier investigations; half of the transgressions would be deleted. Six raised beaches at various altitudes could, for instance, have been formed as a result of only three transgressions.

\section{The formation of raised beaches}

Enough time is needed in the formation of a raised beach for the waves to remove the fine material from the shore, for the accumulation of a boulder rim or for the erosion of a cliff. In the area of uplift in the Baltic raised beaches were formed at times when there was an equilibrium between the water level and the land uplift. This is the case when the rise of the water level is equally fast as the land uplift. Another possibility is that the water level stays at the same level at the same time as there is a standstill in the land uplift. And finally there is an equilibrium when the water level is slowly falling at the same time as there is a subsidence of the land surface. Even if the terms transgression and regression are used in describing the relative land/sea level fluctuations in the Baltic Sea, it is not as a result of their continuous water level changes but also probably because of an irregular land uplift (Hyyppä, 1935).

According to Granö and Roto (1988) raised beaches were formed at the coasts of Finland when the relative water level remained at the same level for 300-1300 years, the standstill being longest at the south coast. As raised beaches were formed at times of an equilibrium between the water level and uplift it can be assumed that before the formation of the raised beach of the Ancylus Sea transgression another beach had formed during the standstill of the relative lowering of the water level at the time of the preceding regression. Similarly the present L II beach of the Litorina Sea could have formed during the relative regression before the beach of the Litorina I transgression was formed. This would explain the presence of raised beaches representing four shoreline positions. In addition, two lower shoreline positions with raised beaches in Setlax south of Porvoo were also related to a regression - transgression cycle 
(Jantunen, 1995). After the beginning of the Litorina Sea stage there were few irregularities in the land/sea level changes $7500-4000$ B.P. and for the formation of four distinct shoreline positions with raised beaches only two relative transgressions with preceding regressions were needed for their formation. From this follows that an older beach formation does not have to be at a higher altitude than a younger raised beach, as has previously been assumed in shoreline studies.

\section{A comparison of fluctuations of the water level of the oceans with changes of the level of the Baltic Sea}

The latest studies of shorelines along the coast of South Africa shows that the ocean level was at least 2-3 m higher than at present at about 4000-5000 B.P., which was its highest Holocene position (Ramsay, 1995), and in South America there is similarly an indication of a high position of the ocean level at the same time (Jerardino, 1995). Further, according to the study of Ramsay (1995), the ocean level rose about $2 \mathrm{~m}$ at 50004500 B.P., which corresponds in time to the transgression of about $3 \mathrm{~m}$ at about 4200 B.P. in Seitlax near Porvoo in southern Finland (Jantunen, 1995). In the diagram presented by Ramsay (1995) that shows the ocean level fluctuations, the levels corresponding to the Finnish Litorina L III and L IV levels can be traced, as seen in Fig. 1. An eustatic transgression at about 4000 B.P. is also supported by the recent demonstration in South Carolina in North America of a climatically controlled Holocene transgression of about $2 \mathrm{~m}$ (Scott and Collins, 1996).

From this explanation of the formation of raised beaches it follows that the oldest Litorina beach $\mathrm{L}$ I in southern Finland was formed after the L II beach, the ages being for L II about 7500 B.P. and for L I 7000 B.P. (Fig. 3). Similarly L IV at about 4800 B.P. is older than the L III beach at a higher altitude dated at 4200 B.P. (Jantunen, 1995). L III was thus formed when the Holocene ocean level reached its highest position.

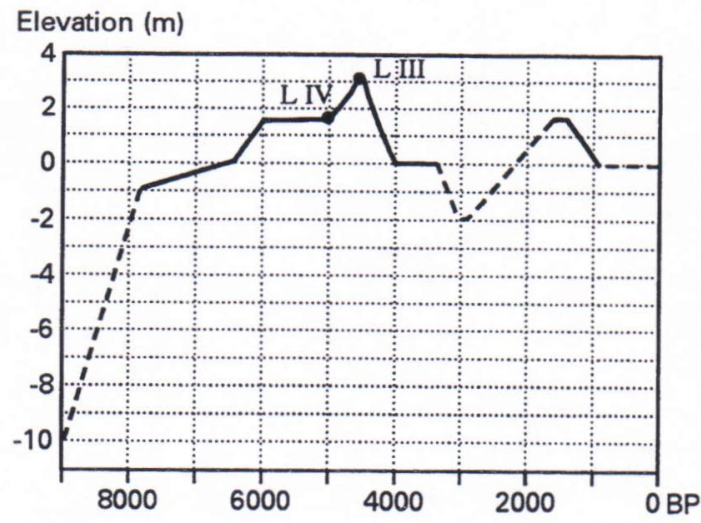

Figure 1. Holocene sea level changes at the coasts of Southern Africa according to Ramsay (1995) and the positions of the L III and L IV shorelines in southern Finland.

The influence of the land uplift and of the Ancient Lake Saimaa on the land/sea level changes in the Baltic Sea

In the study of the land/sea level changes in southern Finland the possible influence of the history of the large lakes of Päijänne and Saimaa has to be considered. Their outflow was first towards the northwest into the Gulf of Bothnia but because of the land uplift they were tilted towards the southeast. After a transgression in these lake basins starting at about 8000 B.P. they formed a large lake complex in central Finland, which was drained when new outlets were formed in the southeast through Vuoksi at about 5000 B.P. into Lake Ladoga and through Kymijoki at 6100 B.P. into the Gulf of Finland for Lakes Saimaa and Päijänne respectively. The history of Lake Saimaa has been studied by, among others, Hellaakoski (1922), Lappalainen (1962), Saarnisto $(1970,1971)$ and Tikkanen (1990). Thus, the lakes had no outlets into the Baltic Sea for over 2000 years. During this period, from 8000 B.P. to $6100-5000$ B.P. when a large lake covered central Finland, the weight of the water may have retarded the land uplift.

When the new outlets were formed and the lakes were drained a few meters to the south 
a.s.l.

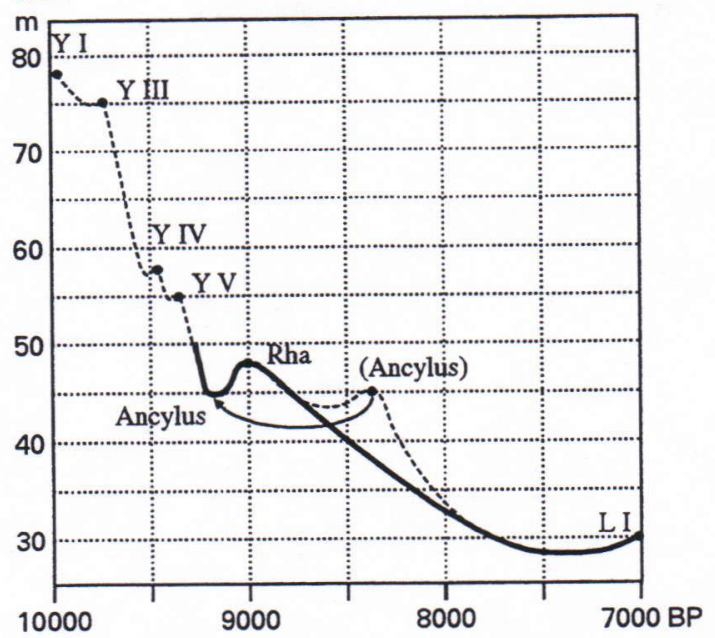

Figure 2. Shoreline displacement curve for southern Finland before the time of the first Litorina transgression, LI, in southern Finland compared with an earlier constructed curve by Donner (1952, dotted line).

into the Litorina Sea there was probably a temporary increase in the rate of uplift which could have been recorded at the south coast as a relative regression of the Baltic level (Fig. 3), without any changes in the water level of the Baltic Sea. With the slowing down of the land uplift the level of the Litorina Sea again rose as

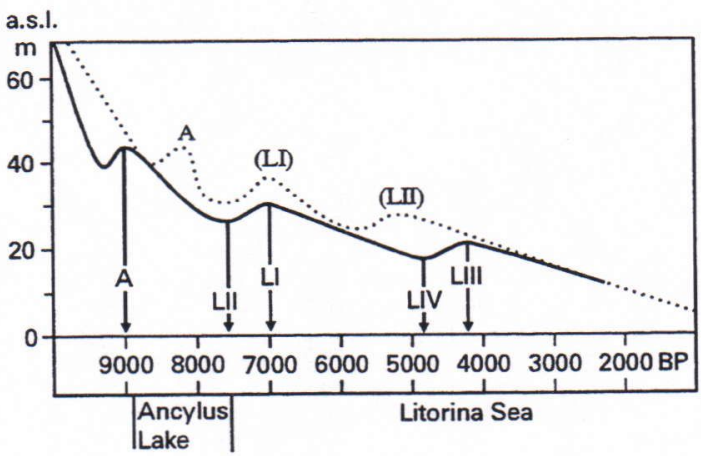

Figure 3. Shoreline displacement curve for southern Finland showing the Ancylus and Litorina shorelines in relation to regressions and transgressions, with the old designation of the beaches retained. Dotted line shows earlier curve constructed by Donner (1969). a result of the $2 \mathrm{~m}$ transgression of the ocean level at about 5000-4500 B.P. (Fig. 1, Ramsay, 1995). Before this transgression the relative position of the water level had been stationary and a beach had formed, which in the Seitlax area is at $14 \mathrm{~m}$ above sea level, and known as the L III beach, but which earlier had been named the L IV beach (Fig. 3). The peak of the transgression of the Litorina Sea was in Seitlax at $17 \mathrm{~m}$ above sea level, and dated at $4500-4000$ B.P., during which the L IV beach (formerly L III) was formed (Jantunen, 1995). Even if there is no direct evidence of an effect of the large central Finnish lake complex on the above-mentioned land/sea level changes at the coast of southern Finland, the possible effect of large water bodies on the isostatic uplift should be considered.

\section{Examples of land/sea level curves}

As examples of the influence of the new interpretation of the formation of raised beaches presented above two figures are given in which new shoreline displacement curves are compared with earlier ones. For the sake of clarity the designation of the beaches have, however, been retained, even if the age sequence has changed. Fig. 2 shows the shoreline displacement before

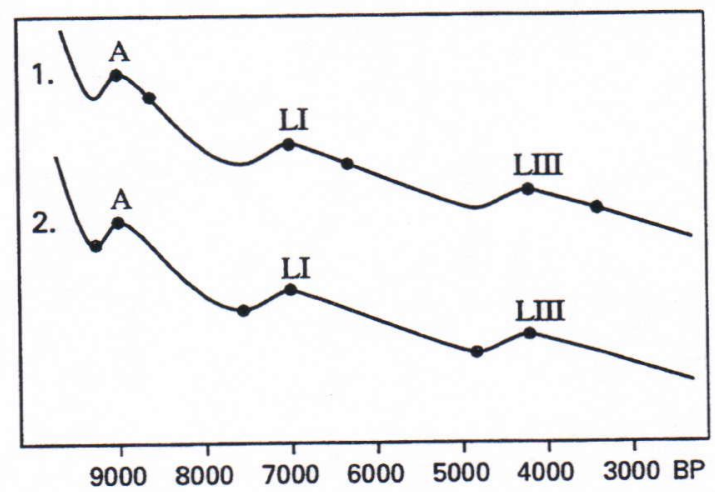

Figure 4. Old interpretation of the age of raised beaches in southern Finland (1) compared with new interpretation (2). 
the Litorina stage. The beach at $45 \mathrm{~m}$ formerly held to represent Ancylus (8400 B.P.) was consequently formed during the regression before the Rha-transgression (the present Ancylustransgression) at about 9300 B.P. This pair of raised beaches found in southern Finland was already mentioned by Sauramo (1949, 1958). The raised beaches from the time of the rapid Yoldia regression are not as clearly developed as those at lower altitudes and do not represent equally clear shoreline positions. They may therefore not necessarily represent regressiontransgression sequences; there is no stratigraphical evidence for this either. Fig. 3 depicts the Litorina beaches, L I of the old curve corresponds to the L I beach in the Helsinki area (Hyyppä, 1950). Even if the L II and L IV beaches seem to have been formed during regressions preceding transgressions it does not necessarily mean that they were formed during low positions of the water level; the shape of the curve could have been influenced by changes in the rate of uplift causing a relative regression. L I and L III, on the other hand, represent real transgressions caused by rises of the ocean level, particularly during the formation of the L III beach.

\section{CONCLUSION}

In investigations of raised beaches they have commonly been regarded as representing a series of formations where the age decreases with decreasing altitude. Further, the beaches have been linked to relative transgressions of the water level and particularly beach ridges have been considered to have been formed only as a result of transgressions. The new order in the formation of the beaches is schematically shown in fig. 4 , in which each beach of a transgression is preceded by an older beach of a regression. In stratigraphically tracing a transgression it is important to find a mire or lake basin which is suitably $(\sim 1 \mathrm{~m})$ below the upper limit of the transgression and has been isolated from the Baltic Sea during the regression before the subsequent transgression. 


\section{REFERENCES}

Donner, J. (1952) On the early Post-Glacial shore-line displacement in southeast Finland. Annales Academiæ Scientiarum Fennicæ. Series A III 29, 22 p.

Donner, J. (1969) Land/sea level changes in Southern Finland during the formation of the Salpausselkä endmoraines. Bulletin of the Geological Society of Finland 41, 135-150.

Eronen, M. (1974) The history of the Litorina Sea and associated Holocene events. Supplement: Pollen and diatom diagrams. Commentationes Physico-Mathematicæ, Societas Scientiarum Fennica 44: 4, 79-185.

Glückert, G. (1991) The Ancylus and Litorina transgressions of the Baltic in Southwest Finland. Quaternary International, Vol. 9, pp. 27-32.

Granö, O. and Roto M. (1988) The Duration of Shore Exposure Along the Emerging Finnish Coast. Journal of Coastal Research, 5: 1, 49-55.

Hellaakoski, A. (1922) Suursaimaa. Fennia 43: 4, 1-122.

Hyyppä, E. (1935) Kivikautinen asutus ja rannan siirtyminen Helsingin seudulla. Terra 47: 1, 31-47.

Hyyppä, E. (1950) Helsingin ympäristö. Maaperäkartan selitys. Geologian tutkimuslaitos, Helsinki, $53 \mathrm{pp}$.

Jantunen, T. (1995) A late Litorina transgression in the district of Porvoo in Southern Finland. Annales
Academiæ Scientiarum Fennicæ. Series A III 158, $1-40$.

Jerardino, A. (1995) Late Holocene Neoglacial episodes in southern South America and southern Africa: a comparison. The Holocene, 5: 3, 361368.

Lappalainen, V. (1962) The shore-line displacement on southern Lake Saimaa. Acta Botanica Fennica 64, $125 \mathrm{p}$.

Ramsay, P. J. (1995) 9000 years of sea-level change along the Southern African coastline. Quaternary International, Vol. 31, pp. 71-75.

Saarnisto, M. (1970) The Late Weichselian and Flandrian history of the Saimaa lake complex. Commentationes Physico-Mathematicæ, Societas Scientiarum Fennica 37, 7-107.

Saarnisto, M. (1971) History of Finnish lakes and Lake Ladoga. Commentationes Physico-Mathematicæ, Societas Scientiarum Fennica 41, 371-388.

Sauramo, M. (1949) Das dritte Scharnier der fennoskandischen Landhebung. Societas Scientiarum Fennica, Årsbok-Vuosikirja 27: 4, 1-26.

Sauramo, M. (1958) Die Geschichte der Ostsee. Annales Academiæ Scientiarum Fennicæ 51, 1-522.

Scott, D. B. and Collins E. S. (1996) Late Mid-Holocene Sea-Level Oscillation: a possible cause. Quaternary Science Reviews, Vol. 15, pp. 851856.

Tikkanen, M. (1990) Suomen vesistöjen jääkauden jälkeinen kehitys. Terra 102: 4, 239-255. 